\title{
The perceived well-being and health costs of exiting self-employment
}

\author{
Milena Nikolova $\mathbb{D} \cdot$ Boris Nikolaev • Olga Popova $(\mathbb{D}$
}

Accepted: 5 June 2020 / Published online: 4 July 2020

(C) The Author(s) 2020

\begin{abstract}
We explore how involuntary and voluntary exits from self-employment affect life and health satisfaction. To that end, we use rich longitudinal data from the German Socio-Economic Panel from 1985 to 2017 and a difference-in-differences estimator. We find that while transitioning from self-employment to salaried employment brings small improvements in health and life satisfaction, the negative psychological costs of business failure (i.e., switching from self-employment to unemployment) are substantial and exceed the costs of involuntarily losing a salaried job. Meanwhile, leaving self-employment has no consequences for selfreported physical health and behaviors such as smoking
\end{abstract}

Electronic supplementary material The online version of this article (https://doi.org/10.1007/s11187-020-00374-4) contains supplementary material, which is available to authorized users.

M. Nikolova $(\bowtie)$

Faculty of Economics and Business, Global Economics and Management, University of Groningen, Groningen, Netherlands e-mail: m.v.nikolova@rug.nl

M. Nikolova

Institute of Labor Economics (IZA), Bonn, Germany

M. Nikolova

The Brookings Institution, Washington, DC, USA

M. Nikolova

Global Labor Organization (GLO), Essen, Germany

B. Nikolaev

Baylor University, One Bear Place \#98011, Waco, TX 76798, USA

e-mail: borisnikolaev@gmail.com and drinking, implying that the costs of losing selfemployment are mainly psychological. Moreover, former business owners fail to adapt to an involuntary selfemployment exit even 2 or more years after this traumatic event. Our findings imply that policies encouraging entrepreneurship should also carefully consider the nonmonetary implications of business failure.

Keywords Entrepreneurship · Self-employment · Health · Well-being · Unemployment · Job switches

JEL codes E24 $\cdot \mathrm{I} 10 \cdot \mathrm{I} 31 \cdot \mathrm{J} 28 \cdot \mathrm{L} 26$

\section{O. Popova}

Leibniz Institute for East and Southeast European Studies (IOS), Regensburg, Germany

e-mail: popova@ios-regensburg.de

\section{O. Popova}

CERGE-EI, a joint workplace of Charles University and the Economics Institute of the Czech Academy of Sciences, Prague, Czech Republic

O. Popova

Graduate School of Economics and Management, Ural Federal University, Yekaterinburg, Russian Federation 


\section{Introduction}

Starting and running a new business venture can be a great source of personal fulfillment and satisfaction (Benz and Frey 2008b; Binder and Coad 2013; Cardon et al. 2012; Shir et al. 2019; Stephan and Roesler 2010). Unlike most traditional occupations, entrepreneurs typically enjoy freedom and control. This enables them to derive more meaning from their work, effectively cope with stress, and utilize their innate talents and skills (Shir et al. 2019; Stephan 2018; Wiklund et al. 2019; Wolfe and Patel 2019). Consequently, entrepreneurship is often viewed as a highly advantageous career, with over two-thirds of people reporting the desire to work for themselves (Parker 2019).

However, the process of starting and running a new business venture is rarely easy and straightforward. Many people who launch new companies terminate their efforts in less than a year (Katz and Gartner 1988; Reynolds et al. 2004; Shane 2008). Only a third of all new ventures have positive cash flow after 7 years (Shane 2008), and two-thirds of all start-ups fail within the first 10 years (Parker 2019). Business failure is pervasive and can not only lead to financial losses but also evoke emotions, such as grief, shame, and selfblame, and low self-esteem (Parker 2019; Shepherd 2003; Ucbasaran et al. 2013). These adverse outcomes can be particularly traumatic for entrepreneurs whose identity is tightly linked to their ventures (Rouse 2016).

This paper investigates the perceived life and health satisfaction costs of exiting self-employment. ${ }^{1}$ A large body of literature has documented a wide range of nonmonetary rewards of being self-employed. For example, these include job and life satisfaction (Benz and Frey 2008a, 2008b; Hessels et al. 2018), lower stress (Hessels et al. 2017), health (Nikolova 2019; Stephan et al. 2020), and eudaimonic well-being (Nikolaev et al. 2020; Shir et al. 2019). These nonmonetary benefits are often attributed to the self-employed having higher levels of job control, autonomy, and utility from purposeful and self-directed work (Hundley 2001; Nikolaev et al. 2020; Shir et al. 2019). Consequently, the public policy recommendations of scientific papers

\footnotetext{
${ }^{1}$ We compare four labor market transitions: (1) self-employment to unemployment (i.e., involuntary business exits), (2) salaried employment to unemployment due to plant closures (i.e., involuntary job loss), (3) self-employment to salaried employment (i.e., voluntary selfemployment exits), and (4) salaried employment to salaried employment (i.e., voluntary job changes).
}

often tout entrepreneurship as a means of enhancing both personal and social welfare. However, this paints a somewhat idealistic picture of the realities that many people who start new ventures go through.

Therefore, to provide a counterbalance to the wellbeing literature in entrepreneurship and help examine the potential trade-offs associated with starting and running a business, we pose the following questions: (1) What is the impact of exiting self-employment on perceived health and subjective well-being? (2) How do the perceived health and life satisfaction effects of exiting self-employment compare to losing a salaried job? (3) Is the impact of exiting self-employment persistent, or do people quickly adapt to this adverse event?

To answer these questions, we use rich longitudinal data from the German Socio-Economic Panel (SOEP), allowing us to track self-employed and salaried workers overtime. Our findings suggest that losing selfemployment and becoming unemployed leads to a decline in psychological well-being. In subsequent analyses, we also show that this drop in life satisfaction is far more severe than the drop associated with losing a salaried job (i.e., switching from salaried employment to unemployment). At the same time, transitioning from self-employment to a salaried position can even be beneficial to life and health satisfaction. Finally, our results suggest that health and life satisfaction declines associated with business failure persist for 2 or more years after losing self-employment.

Our paper makes three contributions to the small business economics literature. First, unlike previous studies, which mostly focus on the positive effects of self-employment, we examine changes in both life and health satisfaction as a consequence of self-employment exits. As such, we build on and extend the work by Hetschko (2016), which, to the best of our knowledge, is the only contribution concerning the psychological costs of losing self-employment in the economics literature to date. Specifically, Hetschko (2016) shows that losing self-employment can lead to more substantial declines in life satisfaction than unemployment due to plant closings. We also compare and contrast the selfreported health and life satisfaction changes of those who involuntarily lose self-employment with those who involuntarily lose a salaried job.

Second, not all business exits are created equal. While some businesses may end up in bankruptcy, others may be liquidated because the founder had better job opportunities elsewhere. Even if the business fails, 
finding salaried employment can significantly alleviate the adverse effects of exiting self-employment by reducing the financial stress associated with unemployment and fulfilling basic psychological needs for structure, shared goals, social contact, status, and activity. Thus, transitioning from self-employment to salaried employment can significantly speed up the recovery process following after exiting self-employment, and, in some cases, even improve psychological well-being, which is a possibility we explore. As such, we consider transitions from self-employment to unemployment to be involuntary while transitions to a salaried job to be voluntary. Admittedly, this classification may appear crude because the survey does not explicitly ask respondents whether labor market transitions are voluntary. Nevertheless, our definition is consistent with traditional approaches to modeling entrepreneurship and job loss. One advantage of this approach is that it objectively defines various transitions, which makes it useful for analytical purposes (Fairlie and Fossen 2018).

Finally, several studies document that people are remarkably adaptable, and life satisfaction typically stabilizes after most life events and shocks (Graham 2011). We contribute to this line of research by studying if the adverse psychological well-being effects of losing selfemployment are likely to persist or dissipate over time. In addition, we complement our analysis by exploring additional health and behavioral outcomes (e.g., sleep satisfaction, BMI, smoking, and drinking) that are relevant to the relationships we study.

\section{Previous literature, theory, and hypotheses}

A large body of literature suggests that job loss can lead to declines in both psychological well-being and physical health (Wanberg 2012). Specifically, being unemployed is linked with a range of stress-related outcomes, including depression, anxiety, low self-esteem, and physical ailments, such as pain and headaches, that can stifle people's ability to function in their daily lives and even lead to suicide. The adverse well-being effects of an unemployment spell can be felt years later, long after workers are reemployed (Clark et al. 2001; Wanberg 2012).

Several theories have been proposed to explain the mechanisms behind unemployment's negative consequences (Bartrum and Creed 2006). The most prominent theoretical perspective is Jahoda's $(1982,1987)$ latent deprivation model. According to this theory, employment is a social institution providing both incomerelated manifest benefits and latent benefits related to fulfilling basic psychological needs. While people mostly work to obtain manifest benefits, work also fulfills five basic psychological needs - time structure, social contact, shared common goals, status, and activity - that are key for psychological well-being. Unemployment deprives people of both the manifest and latent benefits of work. However, it is mostly the loss of latent benefits that leads to lower psychological well-being. An extensive empirical literature supports, at least partially, Jahoda's model (Bartum and Creed 2006).

Other theoretical perspectives such as the CoPES (Coping, Psychological, and Employment Status) model (Waters 2000) have identified a wide range of stressors related to job search, rejection, financial strain, relationship problems, and boredom that can further exacerbate the negative relationship between unemployment and psychological well-being. For example, Price et al. (2002) argue that the severe financial strain associated with unemployment ultimately leads to feelings of helplessness, a lack of control, and depression, which, in turn, contributes to poor mental health over time.

Previous meta-analyses (McKee-Ryan et al. 2005; Paul and Moser 2009) suggest that the negative effect of unemployment on psychological well-being is nonnegligible (Cohen 1992; Wanberg 2012). The proportion of clinically depressed people, for example, is twice as high among the unemployed compared with those who have full employment (Paul and Moser 2009). Of course, reverse causality and selection effects are critical empirical challenges with such studies. Specifically, individuals with poor psychological well-being may also be more likely to lose their jobs. However, several longitudinal studies using data on company closuresan involuntary job loss proxy-show that unemployment is causally related to poor psychological wellbeing outcomes (Kassenboehmer and Haisken-DeNew 2009; Nikolova and Ayhan 2019; Paul and Moser 2009).

Similarly, many studies suggest that unemployment can negatively impact physical health, measured by selfreported health, health-symptoms checklists, and biochemical markers (Korpi 2001; Maier et al. 2006; Strully 2009). Unemployment can also lead to unhealthy behaviors such as smoking, drinking, and weight gain (Deb et al. 2011; Marcus 2014). Theoretically, the stress associated with unemployment can 
directly translate into physical symptoms (Wanberg 2012), increase the probability of mortality, and even lead to suicide (Platt and Hawton 2000). Unemployed people may also be unable to afford healthy food and quality health care so that any health conditions can go untreated for a long time.

Nevertheless, people with poor physical or mental health may be more likely to lose their jobs, which again points to reverse causality issues. Indeed, using US panel data, Strully (2009) finds a significant positive correlation between poor health and subsequently being fired or leaving a job voluntarily. The study also suggests that unemployment is related to the deterioration of mental health beyond these selection effects. Compared with a reference group of people who had stable employment, for example, those who lost their jobs due to company closures were more likely to report poor physical health and an increase in the number of health conditions, such as hypertension, arthritis, or diabetes. Other studies support similar conclusions for symptoms, including chest pain, stomach aches, and backaches, aggregated in a health-symptoms index (e.g., Korpi 2001). Previous unemployment spells have also been correlated with higher levels of the stress hormone cortisol (Maier et al. 2006) and the c-reactive protein (CRP), a marker of inflammation, even 5 to 8 years after the unemployment spell occurred (Janicki-Deverts et al. 2008). Therefore, we expect that:

H1a: An involuntary exit from self-employment to unemployment is associated with lower life and health satisfaction compared with staying self-employed.

H1a: An involuntary exit from salaried employment to unemployment is associated with lower life and health satisfaction compared with staying employed in a salaried job.

The psychological well-being and health consequences of unemployment we discussed above are aggregated across individuals. However, many previous studies suggest that not everyone experiences unemployment in the same way (Gielen and van Ours 2014; Wanberg 2012). In this section, we argue that the negative well-being effects of unemployment are more substantial for those who transition from self-employment to unemployment compared with those who transition from salaried employment to unemployment.
Several risk factors and processes predict psychological well-being during unemployment (McKee-Ryan et al. 2005). Specifically, work centrality (i.e., how important is the work to the individual), cognitive appraisal (i.e., how individuals interpret the job loss), coping resources (i.e., the individual's financial resources and social support), and coping strategies (i.e., the cognitive and behavioral strategies related to dealing with demands during unemployment) moderate the relationship between unemployment and psychological well-being. In this respect, individuals who have a higher sense of self-worth, perceived control, experience less financial strain, and do not strongly identify with their work are more likely to fare better during the unemployment spell and recover faster from the adverse experience (McKee-Ryan et al. 2005; Wanberg 2012).

From this perspective, the unemployment experience after a business exit (i.e., switching from selfemployment to unemployment) can be especially damaging to psychological well-being relative to the experience of unemployment due to a loss of salaried employment (i.e., switching from salaried employment to unemployment). First, there is a strong emotional connection between entrepreneurs and their businesses. Most entrepreneurs see their work as central to their lives, future aspirations, and personal growth and development. In fact, many entrepreneurs are passionate about their ventures beyond the mere potential for financial gain (Cardon et al. 2012). For example, entrepreneurs often view their ventures as their "baby" (Wasserman 2008). Therefore, the potential loss of something central to one's life can be particularly damaging to one's psychological well-being.

Furthermore, research indicates that founders often form deep identity connections with the ventures they start as they pour time, energy, passion, hopes, and resources to nurture their organizations' future growth (Cardon et al. 2012; Rouse 2016). These deep connections make it especially difficult to psychologically disengage during exit events, which can significantly destabilize the founder's identity (Rouse 2016; Cardon et al. 2012). Losing self-employment, for example, is more strongly correlated with feelings of personal failure and deviation of one's ideal self, compared with losing salaried employment (Hetschko et al. 2014).

Appraising the situation as a personal rather than a professional loss may also lead to greater feelings of grief, shame, humiliation, guilt, self-blame, distress, and 
severe anxiety compared with those who lose their salaried employment (Shepherd 2003; Shepherd et al. 2009a, b). This negative emotional response can significantly hinder people's ability to learn from failure and harm their self-efficacy, self-worth, and perceived life control (Shepherd 2003). Thus, because it is more difficult to separate professional from personal failure, as the identity of the entrepreneur is often closely tied to the business, people who enter unemployment after a business loss may be more likely to fare less well psychologically compared with their counterparts who transition to unemployment from salaried employment. The magnitude of the drop in psychological well-being following a self-employment exit may be higher than that of losing a salaried job, even if both groups end up at the same level of subjective well-being as unemployed (Hetschko 2016). This is because the self-employed workers have higher ex-ante well-being levels than salaried workers (Benz and Frey 2008a).

Finally, business failure can lead to substantial financial losses that exceed the declines in income associated with losing a salaried job. Self-employed people are more likely to run into debt and are less likely to receive unemployment insurance benefits than their counterparts in salaried employment (Hetschko 2016; Parker 2019). In addition, the most common source of start-up capital is the entrepreneur's own savings (Parker 2019; Shane 2008). Losing these savings as a result of business failure can deprive entrepreneurs and their families of essential financial resources during the unemployment spell. It can also increase financial strain and feelings of insecurity, further exacerbating the psychological damage of unemployment and making coping with the adverse situation more difficult and prolonged.

In some countries, failed entrepreneurs can also face significant social stigma for many years, which can further prolong the recovery process (Armour and Cumming 2008; Simmons et al. 2014). Consequently, a longer recovery period may be necessary for failed entrepreneurs to bounce back (adaptation to the adverse situation) relative to people losing salaried jobs.

Therefore, we expect that:

H2a: The negative life and health satisfaction impacts associated with unemployment are stronger for people who transition from self-employment compared with those who transition from salaried employment.
H2b: Adaptation to unemployment (the recovery process) is longer for self-employed people compared with their salaried counterparts.

As we argued above, involuntary business exits can have a pervasive and long-lasting negative effect on the psychological well-being and physical health of the founder. However, not all self-employment exits are involuntary. Businesses can be liquidated as a result of a successful acquisition, desired career change, retirement, or some other life event such as a relocation (Coad 2014; Jenkins and McKelvie 2017). Therefore, not all self-employment exits will be appraised as stressful events and lead to negative emotional and health responses (Byrne and Shepherd 2015; Jenkins and McKelvie 2017; Jenkins et al. 2014). Just like people in salaried employment can change jobs and careers to pursue better opportunities for personal growth and development, self-employed people may also voluntarily seek alternative forms of work to improve their lifestyles and well-being. Specifically, voluntary salaried job changes can enhance psychological well-being, at least in the short run (Chadi and Hetschko 2018). Studies in organizational psychology, for example, theorize and find evidence for the so-called honeymoonhangover effect, whereby job satisfaction is higher for individuals who transition from one salaried employment to another within the last year (i.e., the honeymoon effect). Still, this positive effect disappears in subsequent years (i.e., the hangover effect) (Boswell et al. 2005). In turn, higher levels of job satisfaction can positively spill over to physical and mental health (Faragher et al. 2005) and overall life satisfaction (Judge et al. 1998; Judge and Watanabe 1993).

As Bates (2005, p.345) explains, “departure requires only that a superior alternative has become available to the entrepreneur." In that case, it may be reasonable to expect that self-employed people, especially those with high human capital, may voluntarily enter salaried employment if the opportunity cost of keeping the business in operation is too high (Coad 2014; Grilli 2011).

Since entrepreneurs often face high uncertainty, long working hours, time pressure, role conflicts, and ambiguity, starting and running a business can be a significant source of stress (Patzelt and Shepherd 2011; Wincent and Örtqvist 2011). The idea that entrepreneurship is one of the most stressful occupational choices is "ubiquitous" (Uy et al. 2013). While other occupations can undoubtedly be stressful as well, entrepreneurs "lack resources, often work alone, lack support from colleagues, 
and must bear the cost of their mistakes while fulfilling lots of diverse roles such as recruiter, spokesperson, salesman, and boss" (Cardon and Patel 2015). Thus, voluntary transitions from self-employment to salaried employment can, in some cases, lead to improved psychological well-being and health outcomes, especially for those who may find it challenging to cope with the increased demands and stress of being your own boss.

Transitioning from self-employment to salaried employment can significantly alleviate the financial strain and psychological distress that immediately follow the business exit by providing founders with a new source of income and fulfilling basic psychological needs for time structure, social contact, shared common goals, status, and activity. For example, in a sample of 256 entrepreneurs who filed for bankruptcy, Jenkins and McKelvie (2017) found that while about $80 \%$ of entrepreneurs reported being considerably or somewhat worse after transitioning to unemployment, close to $40 \%$ of self-employed people who transitioned to salaried employment reported being considerably better off, somewhat better off, or neither better nor worse off.

However, self-employment transitions, even when voluntary (i.e., switches from self-employment to salaried employment), may have negative well-being consequences for the reasons we outlined earlier. For instance, founders may have a difficult time letting go of their business even when the exit is a result of a successful acquisition (Rouse 2016). Similarly, Ronstadt (1986) found that most founders who either sold or liquidated their business described their self-employment careers as "financially disappointing" (p. 335).

Taken together, the evidence above leads to our last hypothesis:

H3: Voluntary transitions from one salaried job in the private sector to another one result in higher positive psychological well-being and perceived health benefits relative to changes from selfemployment to salaried employment.

\section{Data}

\subsection{Dataset}

We rely on longitudinal data from the German SocioEconomic Panel (SOEP), version 34 (Goebel et al.
2019; Wagner et al. 2007). The SOEP is a nationally representative household panel of individuals aged 18 and older that has been available since 1984, with East Germany added in 1990. The dataset provides detailed information on well-being, health, labor market history, and household and sociodemographic characteristics. Since 2002, the SOEP has included a Health Module available every 2 years. To ensure sufficient statistical power for our analyses and to prevent a loss of observations due to the less frequent nature of the Health Module compared with the rest of the SOEP dataset, we primarily rely on information from the regular SOEP longitudinal module. The data in our main analysis sample span 1985-2017. ${ }^{2}$ In robustness checks, we include information from the Health Module. ${ }^{3}$

\subsection{Sample restrictions, treatment, and comparison} groups

We restrict the analysis sample to adults aged 18 to 60 to avoid health-induced self-employment exits among older workers. Our definition of salaried workers includes only private sector employees and excludes any civil servants and government workers. ${ }^{4}$ Both salaried employees working in the private sector and the selfemployed are working full-time. The self-employed may or may not employ others, and we include selfemployed farmers and helpers in the family business.

Unemployed individuals are those who are currently registered with the German Employment Office (Arbeitsamt). Salaried workers who lose their job are asked for the reason for the termination of their last job, which allows us to identify those who become jobless due to plant closures. This "company closure" or "plant closure" variable is often considered a proxy involuntary job loss because typically, individual employees cannot influence whether the firm will remain in business or not (Kassenboehmer and Haisken-DeNew 2009; Nikolova and Ayhan 2019). Plant closure information is

\footnotetext{
$\overline{2}$ The construction of the self-employment exits and job switch variables requires information on the labor force and occupation status of the individual in the previous year.

${ }^{3}$ Specifically, in Table A7, we use as dependent variables the mental component scale, the physical component scale, and the body mass index available in the Health Module.

${ }^{4}$ Civil servants in Germany have different working conditions, including job security, pension contributions, retirement age, and benefits compared with the self-employed and salaried workers in the private sector.
} 
available in the SOEP since 1991, except for 1999 and 2000.

Testing this paper's hypotheses requires the creation of four different treatment and comparison groups. Our first treated group captures involuntary business exits by those who switch from self-employment to unemployment. Respondents in this treated group were fulltime self-employed in the previous survey wave but are registered unemployed in the consecutive one. The matched comparison group consists of individuals who remain continuously self-employed in both survey years. The second treated group reflects the involuntary loss of salaried employment. Individuals in this group were salaried employees in the previous wave but in the current survey are registered unemployed due to company closure. The matched control group consists of individuals who remain continuously employed in both survey periods. Our third treated group includes respondents who voluntarily exit self-employment to become salaried workers. This treated group is based on individuals who reported being self-employed in the previous wave but in the current wave work in the private sector as salaried employees. The comparison group is based on respondents who remained continuously selfemployed in both surveys. Finally, our fourth treated group reflects voluntary job changes from one private sector job to another one. The treated individuals are those who switch salaried jobs between two survey waves. The comparison group comprises interviewees that remained in the same salaried employment position in both interviews.

\subsection{Variables}

Our outcome variables are based on self-reported information on self-reported health and well-being (Table A1). Specifically, we consider life and health satisfaction, both of which are measured on a scale of 0 (completely dissatisfied) to 10 (completely satisfied). Table A2 demonstrates the pre- and post-period summary statistics information for these variables for all analysis samples.

Like Nikolova (2019), we rely on a large number of conditioning variables, detailed in Table A1, which include sociodemographic and labor market characteristics such as age, sex, marital status, real disposable household income, household size, tenure, working hours, type of health insurance, and initial health and well-being status. We include a health insurance control (i.e., government, private, or no insurance). The selfemployed in Germany are typically privately insured but may become uninsured if they lose their business, despite the country's universal healthcare system. All conditioning variables are lagged one time period and capture the initial conditions right before experiencing the switch in the labor market state.

\section{Empirical strategy}

\subsection{Entropy balancing and difference-in-differences}

Entering and leaving self-employment or salaried employment may be correlated with one's pre-existing health and well-being levels, which poses a significant threat to causality. For example, those who are dissatisfied with their health or have poor psychological wellbeing may selectively enter self-employment to manage their conditions or exit to salaried employment if their health and well-being improve. Alternatively, individuals who start and run new business ventures may be more likely to become unemployed if their psychological well-being or health worsens. A second empirical challenge arises because the decision to exit or enter self-employment inherently depends on people's unobservable and unmeasurable traits, which are correlated with both employment decisions and health and wellbeing outcomes. Such characteristics may include, for example, unobserved ability or entrepreneurial aptitude.

We deal with these issues by following a methodology that utilizes a difference-in-differences estimator applied after a nonparametric matching procedure called entropy balancing (Hainmueller 2012; Hainmueller and $\mathrm{Xu} 2013) .{ }^{5}$ Our methodology includes two steps: (i) a data pre-processing using entropy balancing to create comparable groups of individuals who are statistically identical except that the treated group experiences a change in their labor market status between two survey waves while the comparison group does not; and (ii) estimating a weighted regression of the treatment (change in labor market status) on the change in perceived life and health satisfaction status based on weights obtained in step 1 . This empirical strategy allows us to eliminate selection based on the observables

\footnotetext{
${ }^{5}$ Examples of other recent studies following this strategy include Chadi and Hetschko (2018), de Bruin et al. (2011), Kunze and Suppa (2020), Marcus (2013), and Nikolova (2019).
} 
in step 1 and net out time-invariant unobservables that influence both changes in employment status and wellbeing through the difference-in-differences (DID) in step 2 . $^{6}$

The entropy balancing is a pre-processing step ensuring the similarity of treatment and control groups based on observable characteristics. With traditional propensity score matching methods falling out of favor in the scientific community (King and Nielsen 2019), entropy balancing has emerged as a viable alternative. Its advantages over propensity score matching methods include efficiency, improving covariate balance, and eliminating researcher discretion regarding the choice of tolerance levels and the covariates (Hainmueller 2012). Instead of generating propensity scores, entropy balancing "matches" individuals in the treatment and control groups by generating weights, which allow achieving balance in terms of the mean and variance of the covariate distributions of both the treated and comparison groups.

The DID estimators assume that in the absence of treatment, the overall life and health satisfaction outcomes of the treated and comparison groups would follow the same trajectories (i.e., the parallel trends assumption). Nevertheless, this assumption is unlikely to hold in our setting due to selection into selfemployment based on health (Rietveld et al. 2015). One standard solution is controlling for the values of the pre-treatment health and well-being outcomes to ensure that both the treated and control groups have the same starting point (O'Neill et al. 2016; Ryan et al. 2019). Furthermore, we include the pre-treatment values of health and psychological well-being as part of the matching covariates and the DID regression because healthier or happier individuals may choose to leave self-employment or change jobs. This ensures that preexisting psychological or physical health conditions cannot influence the decision to exit self-employment or change salaried jobs in the private sector-i.e., individuals in both the treatment and comparison groups have the same baseline health and psychological wellbeing levels.

Using entropy balancing, we create four matched analysis samples to compare switches from (i) self-

\footnotetext{
${ }^{6}$ Examples of observable characteristics include variables, such as age, education, and work experience, while time-invariant unobservables may comprise factors such as individual idiosyncrasies, dispositional personality traits, and unobserved ability.
}

employment to registered full-time unemployment, (ii) salaried employment to unemployment due to a company closure, (iii) self-employment to salaried employment, and (iv) one salaried job in the private sector to another one (job switches). Each of the four treated groups comprises respondents switching from the original labor market state (self-employment or salaried employment) between two consecutive survey periods. The comparison group always includes individuals who remain in the initial labor market for both survey periods. For example, when examining switches from selfemployment to salaried employment, individuals in the treated group exit self-employment and enter salaried employment in the private sector between two survey periods, while individuals in the control group remain self-employed in both periods. As explained, we ensure that treated and comparison individuals are statistically indistinguishable from one another based on their pretreatment characteristics, including health status, labor market experience, and household and sociodemographic features. The balancing tests are available in Tables A3-A6.

We estimate the average treatment effect (ATT) based on a specification that models the changes in psychological well-being or health status of an individual (WH) $i$ as a result of changes in employment status (ES). ${ }^{7}$

$\Delta \mathrm{WH}_{\mathrm{i}}=\alpha+\beta \mathrm{ES}_{\mathrm{i}}+\mathrm{X}_{\mathrm{i}}^{\prime} \Omega+\varepsilon_{\mathrm{i}}$

We include pre-treatment (i.e., lagged one time period) values of the conditioning variables $X_{\mathrm{i}}$. These variables include age, education, height, migration background, marital status number of children, household size, income and wealth, unemployment experience, disability status, health insurance, state of residence, and others (see Table A1). The treatment effects are already mean-independent due to the entropy balancing. We include the pre-treatment covariates to reduce the unexplained variance in changes in life and health satisfaction and improve the precision.

\subsection{Anticipation and adaptation effects}

The effects we identify using Eq. (1) are short run only. To furnish a complete picture and test hypothesis $\mathrm{H} 2 \mathrm{~b}$,

\footnotetext{
${ }^{7}$ The identifying assumption for the DID matching estimator is that the matching covariates include all influences that simultaneously affect the changes in life and health satisfaction and changes in employment status.
} 
we also explore whether individuals expect and adapt to losing self-employment. Specifically, following Clark and Georgellis (2013) and Nikolova and Ayhan (2019), the life satisfaction or health satisfaction $W H$ of each individual $i$ at time $t$ is given by:

$$
\begin{aligned}
\mathrm{WH}_{\mathrm{it}}= & \alpha+\beta_{-3} U_{-3, \mathrm{it}}+\beta_{-2} U_{-2, \mathrm{it}}+\beta_{-1} U_{-1, \mathrm{it}} \\
& +\beta_{0} U_{0, \mathrm{it}}+\beta_{1} U_{1, \mathrm{it}}+\beta_{2} U_{2, \mathrm{it}}+X{ }_{\mathrm{it}} \Omega \\
& +\pi_{\mathrm{i}}+\tau_{\mathrm{t}}+\varepsilon_{\mathrm{it}}
\end{aligned}
$$

whereas in Eq. (1), $X$ is a vector of covariates ${ }^{8}$ and $\pi$ and $\tau$ are individual and year fixed effects. We estimate Eq. (2) for two analysis samples: (1) individuals who involuntarily transition from self-employment to unemployment and (2) individuals who involuntarily become jobless after losing salaried work due to company closure. The leads of the indicator for involuntary selfemployment or salaried employment exits $\left(U_{-1}, U_{-2}\right.$, and $U_{-3}$ ) capture anticipation effects by counting down the time to future unemployment entry. The dummy variables $U_{-1}, U_{-2}$, and $U_{-3}$ are coded as 1 if the individual will lose self-employment (salaried employment) in the next 1-2 years, 2-3 years, and 3 years or more years, respectively, and 0 otherwise. Similarly, $U_{0}$ denotes the first year of unemployment after losing selfemployment (employment), and the binary indicators $U_{1}$ and $U_{2}$ capture adaptation to losing selfemployment (employment). They take the value of 1 if the respondent has been unemployed after losing selfemployment (employment) for 1-2 years and 2 or more years, respectively, and 0 otherwise. Given that the binary indicators $U_{1}, U_{2}, U_{0}, U_{-1}, U_{-2}$, and $U_{-3}$ are mutually exclusive, any individual is observed in only one of the six groups in any given year. Therefore, when estimating Eq. (2), we use $U_{-3}$ as the reference (i.e., omitted) category. As we estimate (2) using fixed effects models, the comparison is within individual and with respect to the omitted category $U_{-3}$. For example, the coefficient estimate of $U_{1}$ denotes the change in life (or health) satisfaction for respondents who have been unemployed for 1-2 years compared with the life or health satisfaction scores of the same individuals 3 (or more)

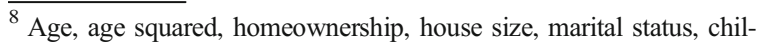
dren in the household, real disposable household income, unemployment experience, education, health insurance, disability status, year dummies, and state dummies. Since we estimate Eq. (2) using a fixed effects estimator, we do not include time-invariant characteristics, such as gender, migration background, and height, which we use in the firststep entropy balancing for estimating Eq. (1).
}

years before losing self-employment or salaried employment.

\section{Results}

\subsection{Involuntary employment changes}

Table 1 documents the life and health satisfaction effects of involuntary job changes, i.e., switches from selfemployment to unemployment (Panel A) and salaried employment to unemployment (Panel B). Switching from self-employment to unemployment significantly reduces life satisfaction and slightly damages health satisfaction (Panel A), which provides support for H1a. Specifically, losing self-employment decreases life satisfaction by 1.4 points and health satisfaction by about 0.3 points. While both the treatment and control groups start at average life satisfaction levels of 6.2 (by construction), the life satisfaction of those who experience business failure drops to 5.0 following the loss of self-employment, while the life satisfaction of those who remain continuously self-employed increases very lightly to 6.4 (See Table A2). The health satisfaction declines induced by losing self-employment are smaller in magnitude compared with the dramatic life satisfaction drop. Health satisfaction falls from 6.6 to 6.3 points for those experiencing a business exit to unemployment, while it remains stable for those who are continuously self-employed (the comparison group). These results are likely because involuntary self-employment exits are seen as life failures, which are damaging the psychological well-being of the former owner. Simultaneously, the psychological costs only partially spill over to the perceived health aspects of life.

We compare the magnitudes of the changes in life satisfaction and health satisfaction induced by losing self-employment (Panel A in Table 1) to those resulting from losing salaried employment (Panel B in Table 1), also depicted in Fig. 1. Involuntary job loss due to plant closings decreases life satisfaction by about 1 point on a $0-10$ scale, which is similar to the magnitude reported in previous studies (Kassenboehmer and Haisken-DeNew 2009; Nikolova and Ayhan 2019). Meanwhile, according to the results in Panel B, health satisfaction is unaffected by involuntarily losing salaried employment, which is in line with Schmitz (2011). Therefore, the evidence supports $\mathrm{H} 1 \mathrm{a}$ and partially $\mathrm{H} 1 \mathrm{~b}$ and suggests that involuntary unemployment following both self- 
Table 1 Entropy balancing DID results, involuntary selfemployment exit vs. an involuntary loss of salaried employment

\begin{tabular}{lll} 
& $(1)$ & $(2)$ \\
& $\Delta$ Life & $\Delta$ Health \\
& satisfaction & satisfaction \\
\hline Panel A: switches from self-employment to unemployment \\
Self-employment to & $-1.399^{* * *}$ & $-0.262^{* *}$ \\
unemployment & $(0.117)$ & $(0.116)$ \\
Pre-treatment covariates & Yes & Yes \\
Treatment group $(N)$ & 240 & 243 \\
Comparison group $(N)$ & 18,056 & 18,078 \\
$R^{2}$ & 0.410 & 0.369 \\
& & \\
Panel B: switches from salaried employment to unemployment \\
due to plant closure & & \\
Private employment to & $-1.006^{* * * *}$ & -0.074 \\
unemployment & $(0.066)$ & $(0.067)$ \\
Pre-treatment covariates & Yes & Yes \\
Treatment group $(N)$ & 645 & 645 \\
Comparison group $(N)$ & 138,761 & 138,470 \\
$R^{2}$ & 0.337 & 0.322 \\
\hline Source: Authors' calculation & & \\
\hline
\end{tabular}

Source: Authors' calculations based on SOEP v.34

Robust standard errors in parentheses: $* * * p<0.01, * * p<0.05$, $* p<0.1$. All regressions include the lagged pre-treatment characteristics (see Table A1 for a list of the covariates and Tables A3A4 for balancing tests). The key independent variable in Panel A is coded as 1 for those switching from self-employment to unemployment between two survey waves and 0 for those who remain continuously self-employed. The key independent variable in Panel $\mathrm{B}$ is coded as 1 for those switching from salaried employment in the private sector to unemployment due to company closure between two survey waves and 0 for those who remain continuously selfemployed. See Table A1 for detailed variable definitions

employment and salaried employment worsens life satisfaction. Some of these psychological costs are also reflected in the lower health satisfaction, but only for former business owners who involuntarily gave up their ventures.

Comparing the results in Panel A and Panel B of Table 1 provides partial support for hypothesis $\mathrm{H} 2 \mathrm{a}$. Specifically, involuntarily losing self-employment is more harmful to psychological well-being than the involuntary loss of a salaried job. Specifically, following Paternoster et al. (1998), we tested for the equality of coefficients across the models assuming the samples are independent. The resulting z-statistic of 2.9 leads to the conclusion that the life satisfaction drop following losing self-employment is higher than that following company closures. The differences are not statistically different between Panels A and B of Table 1 for the health satisfaction outcome $(z=1.40)$.

\subsection{Anticipation, adaptation, and involuntary job changes}

We test $\mathrm{H} 2 \mathrm{~b}$ by analyzing whether individuals can anticipate and/or adapt to the involuntary loss of selfemployment and salaried work. The anticipation and adaptation effects to life events, such as poverty, unemployment, and becoming self-employed, are welldocumented (Clark 2016; Clark et al. 2016; Clark and Georgellis 2013; Georgellis and Yusuf 2016; Hanglberger and Merz 2015; Nikolova and Ayhan 2019; Qari 2014; Zimmermann and Easterlin 2006). Nevertheless, to our knowledge, we are the first to explore the anticipation and adaptation consequences of losing self-employment and becoming unemployed in terms of both life and health satisfaction.

Figure 2 demonstrates the results concerning switches from self-employment to unemployment, and Fig. 3 depicts changes from salaried employment to unemployment due to company closure. Both figures demonstrate within-person changes, whereby the left panel in each graph shows the findings for life satisfaction, while the right panel presents the results for health satisfaction. Figure 2 indicates that life satisfaction starts falling more than 2 years before losing self-employment, while health satisfaction begins declining 1 to 2 years before involuntarily losing self-employment. Importantly, the life and health satisfaction scores of entrepreneurs whose businesses fail do not return to the baseline, even two or more years after this traumatic event.

Individuals who lose salaried employment due to company closure do not experience changes in health satisfaction (Fig. 3). Nevertheless, life satisfaction starts falling already 1 to 2 years before the involuntary job exit and does not return to its previous level, even 2 or more years after this event.

Comparing the results from Figs. 2 and 3, we conclude that losing self-employment has much more severe and long-lasting effects on psychological wellbeing than involuntarily losing a salaried job. The adverse effects of losing self-employment are reflected in both the steeper health and life satisfaction decreases following business failure and the longer adaptation periods. 


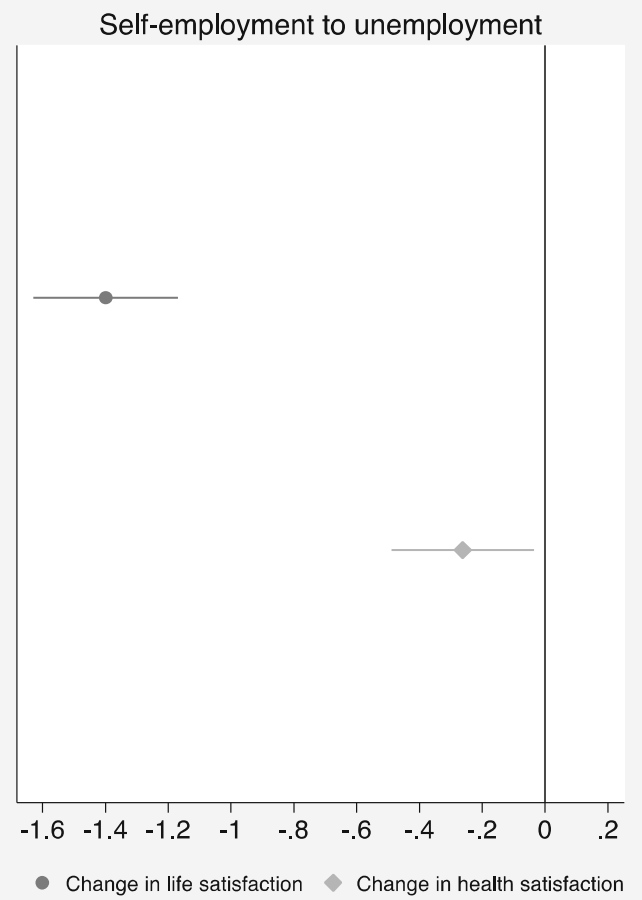

Fig. 1 Life satisfaction and health satisfaction changes due to switching from self-employment to unemployment and salaried employment to unemployment, with $95 \%$ confidence intervals, Source: Authors' calculations based on SOEP v.34. The figure illustrates the estimated changes in life satisfaction and health satisfaction following the switch from self-employment to unemployment based on Table A, models (1)-(2) in the left panel and

\subsection{Voluntary employment changes}

Next, we also analyze the physical health and psychological well-being consequences of voluntary switches from (i) self-employment to salaried employment (Panel A of Table 2) and (ii) between salaried jobs in the private sector (Panel B of Table 2, respectively).

The results in Table 2 provide a direct test of $\mathrm{H} 3$. Specifically, they suggest that individuals who voluntarily switch from self-employment to salaried employment enjoy modest increases in life and health satisfaction compared with individuals who stay continuously self-employed (Panel A) and to those who remain in their private sector salaried jobs (Panel B). In both cases of voluntary employment switches, the gain in life satisfaction is at most 0.1 point, which is relatively small. These results suggest that

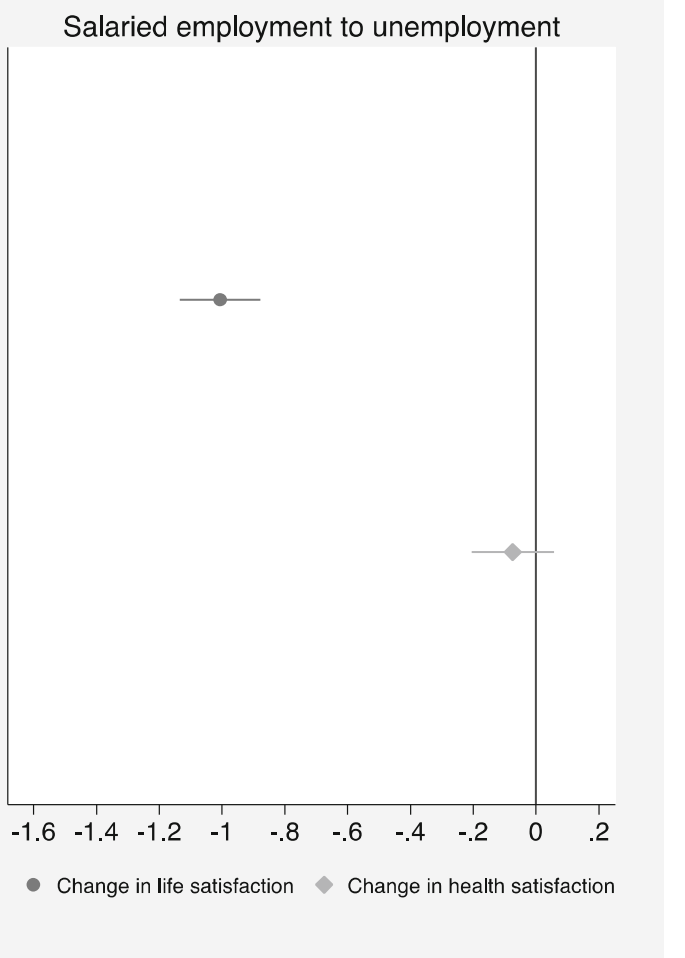

salaried employment to unemployment due to a company closure based on models (1)-(2) in Table 1, Panel B in the right panel. The estimates are based on difference-in-differences estimations. The dashed lines refer to the $95 \%$ confidence interval. Life satisfaction and health satisfaction are measured on a scale ranging from 0 (completely dissatisfied) to 10 (completely satisfied)

voluntarily switches to a salaried job (either from self-employment or salaried employment) can lead to an improvement in perceived well-being and have psychological costs, compared with exits resulting in unemployment. In addition, the life and health satisfaction increases for both groups are very similar in terms of magnitude, suggesting that job switches to salaried employment are equally beneficial across the board. Yet, the so-called "honeymoon" effect associated with switching from one salaried job to another is relatively modest in terms of magnitude, at least in German labor markets. Our findings also imply that finding alternative employment can be a great way to cushion the adverse well-being effects associated with business failure. All in all, our results do not provide support for $\mathrm{H} 3$. 


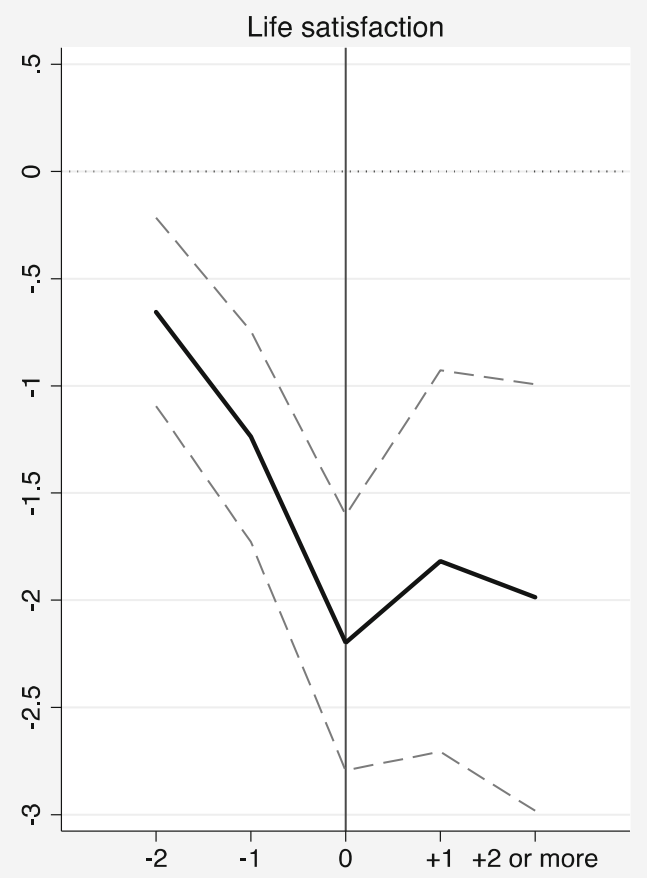

No. years before and after losing self-employment

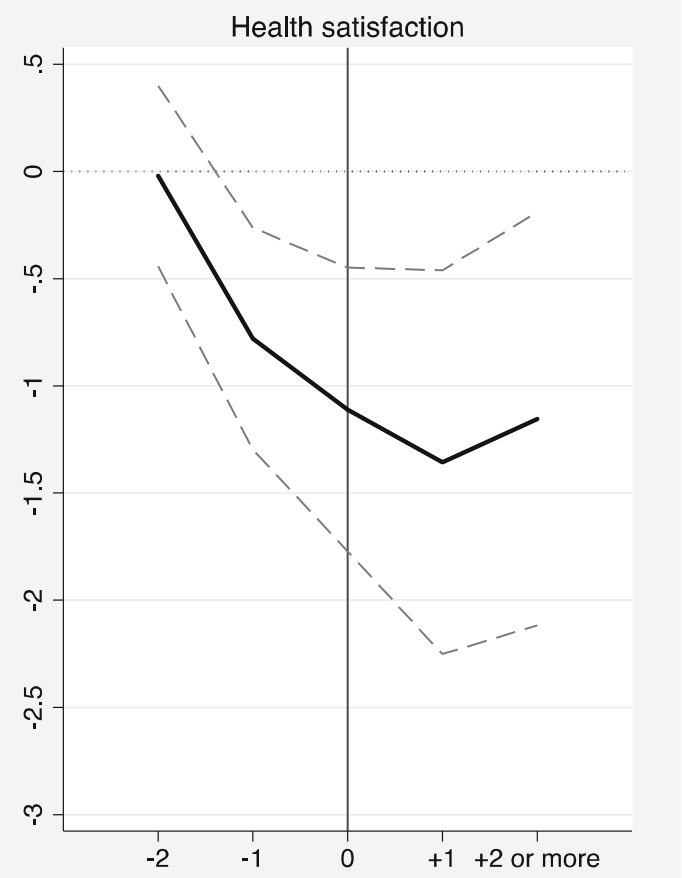

No. years before and after losing self-employment
Fig. 2 Anticipation and adaptation of switching from selfemployment to unemployment, life satisfaction, and health satisfaction, with $95 \%$ confidence intervals. Source: Authors' calculations based on SOEP v.34. The figure shows the lead and lagged unemployment dummies' coefficient estimates from the fixed effects estimation of Eq. (2). The left panel depicts changes in life, and the right panel illustrates the results for health satisfaction. While the dashed lines represent the $95 \%$ confidence interval, the solid line denotes the coefficient estimates of $\left\{\mathrm{U}^{\mathrm{S}}{ }_{-2}, \mathrm{U}^{\mathrm{S}}{ }_{-1}, \mathrm{U}_{0}^{\mathrm{S}}\right.$, $\left.\mathrm{U}^{\mathrm{S}}, \mathrm{U}^{\mathrm{S}}{ }_{2}\right\}$ from Eq. (2). The $\mathrm{x}$-axis indicates the number of years

\subsection{Other dependent variables}

We also analyze whether voluntary and involuntary exits from self-employment affect specific mental and physical health outcomes and behaviors. The results, which are based on individual fixed effects regressions, are shown in Table A7 and demonstrate that involuntary exits from self-employment to unemployment lead to a substantial decrease in mental health (on average, about $78 \%$ of a standard deviation). Nikolova (2019) shows that switching from unemployment to self-employment increases mental health by about $38 \%$ of a standard deviation. Our findings, along with Nikolova (2019), imply that the mental health costs of business failure far outweigh the gains of escaping unemployment and becoming self-employed. Meanwhile, physical health before and after losing self-employment. The y-axis designates the change in the satisfaction outcome. The reference category is $U_{-3}^{S}$, i.e., 3 or more years before losing self-employment. The coefficient estimates should be interpreted as the within-person change in life or health satisfaction with respect to the score 3 (or more) years before that person loses self-employment and becomes unemployed. Life satisfaction is measured on a scale ranging from 0 (completely dissatisfied) to 10 (completely satisfied)

indicators, including the physical component scale, sleep satisfaction, body mass index, and engaging in risky behaviors, are unaffected by involuntary exits from self-employment to unemployment. Therefore, changes in life and health satisfaction that follow after exiting from self-employment to unemployment are likely due to worsening mental health. Meanwhile, Table A7 also demonstrates that voluntary switches from self-employment to salaried employment do not affect mental or physical health markers.

\section{Limitations and suggestions for future research}

Our work has several limitations that also highlight possible directions for future research. First, 


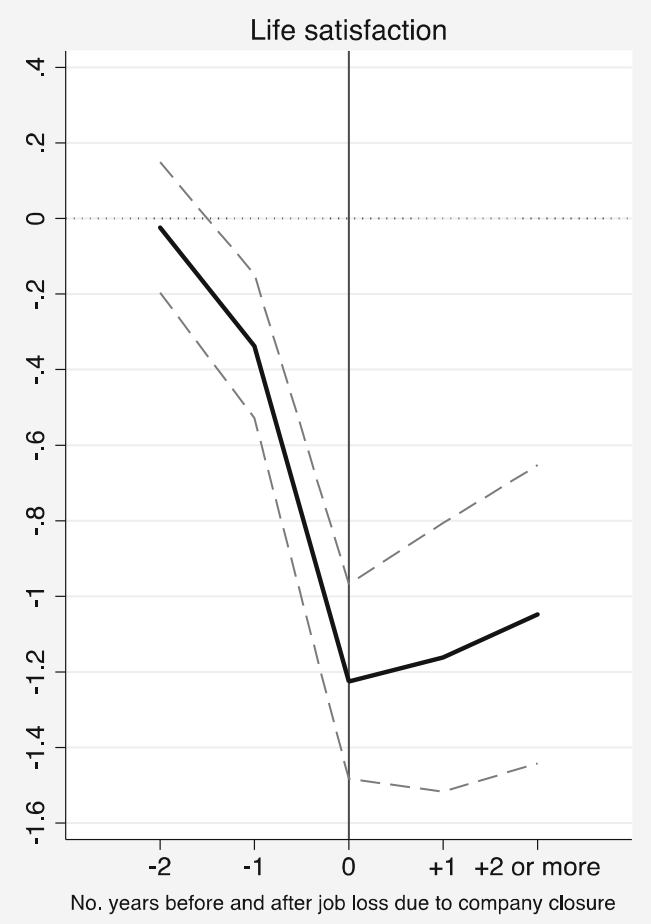

Fig. 3 Anticipation and adaptation of becoming unemployed due to company closure, life satisfaction and health satisfaction, with 95\% confidence intervals. Source: Authors' calculations based on SOEP v.34. The figure shows the lead and lagged unemployment dummies' coefficient estimates from the fixed effects estimation of Eq. (2). The left panel depicts changes in life, and the right panel illustrates the results for health satisfaction. While the dashed lines represent the $95 \%$ confidence interval, the solid line denotes the coefficient estimates of $\left\{\mathrm{U}^{\mathrm{S}}{ }_{-2}, \mathrm{U}^{\mathrm{S}}{ }_{-1}, \mathrm{U}^{\mathrm{S}}{ }_{0}, \mathrm{U}_{1}^{\mathrm{S}}, \mathrm{U}^{\mathrm{S}}{ }_{2}\right\}$ from Eq. (2). The $\mathrm{x}$-axis indicates the number of years before and after losing a

while we document the magnitudes of the health and life satisfaction changes induced by losing self-employment, our paper does not focus on the underlying channels and mechanisms behind them. As such, further explorations are needed to understand the extent to which unemployment benefits, social safety nets, financial worries and debt, or social stigma can potentially mediate or moderate the effects we document.

Second, future research can examine whether the results we document hold across different contexts and countries at varying levels of development while also paying attention to self-selection and causality issues. Such methodological concerns are becoming of growing importance in small business economics and

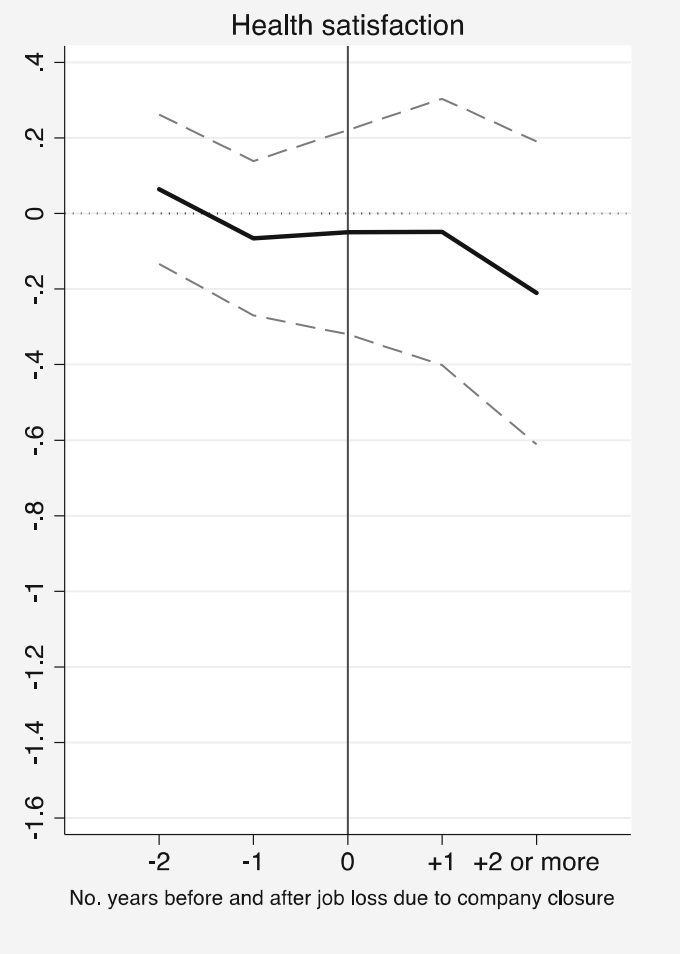

salaried job due to a plant closure. The y-axis designates the change in the satisfaction outcome. The reference category is $U_{-3}^{S}$, i.e., 3 or more years before losing a salaried job due to a plant closure. The coefficient estimates should be interpreted as the within-person change in life or health satisfaction with respect to the score 3 (or more) years before that person loses a salaried job due to a plant closure and becomes unemployed. Life satisfaction is measured on a scale ranging from 0 (completely dissatisfied) to 10 (completely satisfied)

entrepreneurship studies (Stephan et al. 2020). This may be a challenging task, not least because of the scarcity of panel datasets containing relevant information on health and well-being.

Third, future research can also compare the physical and mental health costs of different employment transitions and their pecuniary and non-pecuniary implications. Finally, given the spillover effects of unemployment within the family (Bubonya et al. 2017; Nikolova and Ayhan 2019), future research can also examine how losing a business affects the health and well-being of other family members. We hope that our work will motivate further and more in-depth explorations of this topic and will address some of the lingering questions that our paper raises. 
Table 2 Entropy balancing DID results, voluntary self-employment exit vs. voluntary changes from one salaried job to another

\begin{tabular}{|c|c|c|}
\hline & $\begin{array}{l}(1) \\
\Delta \text { Life } \\
\text { satisfaction }\end{array}$ & $\begin{array}{l}(2) \\
\Delta \text { Health } \\
\text { satisfaction }\end{array}$ \\
\hline \multicolumn{3}{|c|}{ Panel A: switches from self-employment to private employmen } \\
\hline $\begin{array}{l}\text { Self-employment to private } \\
\text { employment }\end{array}$ & $(0.045)$ & $\begin{array}{l}0.103 * * \\
(0.048)\end{array}$ \\
\hline Pre-treatment covariates & Yes & Yes \\
\hline Treatment group $(N)$ & 1182 & 1180 \\
\hline Comparison group $(N)$ & 18,056 & 18,078 \\
\hline$R^{2}$ & 0.307 & 0.284 \\
\hline \multicolumn{3}{|c|}{$\begin{array}{l}\text { Panel B: switches from salaried employment to salaried } \\
\text { employment (job changes) }\end{array}$} \\
\hline $\begin{array}{l}\text { Private employment to private } \\
\text { employment }\end{array}$ & $\begin{array}{l}0.079 * * * \\
(0.016)\end{array}$ & $\begin{array}{l}0.110 * * * \\
(0.018)\end{array}$ \\
\hline Pre-treatment covariates & Yes & Yes \\
\hline Treatment group $(N)$ & 13,852 & 13,726 \\
\hline Comparison group $(N)$ & 144,909 & 144,764 \\
\hline$R^{2}$ & 0.296 & 0.287 \\
\hline
\end{tabular}

Source: Authors' calculations based on SOEP v.34

Robust standard errors in parentheses: $* * * p<0.01, * * p<0.05$, $* p<0.1$. All regressions include the lagged pre-treatment characteristics (see Table A1 for the list of the covariates, and Tables A5A6 for balancing tests). The key independent variable in Panel A is coded as 1 for those switching from self-employment to salaried employment between two survey waves and 0 for those who remain continuously self-employed. The key independent variable in Panel B is coded as 1 for those switching from one salaried job in the private sector to another salaried job in the private sector between two survey waves and 0 for those who remain continuously in their current job. See Table A1 for detailed variable definitions

\section{Discussion and conclusion}

The entrepreneurship literature has so far mainly focused on the well-being benefits of starting and running new business ventures. A growing body of work suggests that self-employed people enjoy several advantages, such as autonomy, competence, and meaning that can lead to higher levels of job satisfaction. However, the implications of these findings may paint an overly optimistic picture of what it means to be "your own boss." After all, the vast majority of new businesses fail, implying that business exits are a common experience.

Our paper contributes to the literature on entrepreneurial well-being by focusing on the underwhelming but widespread experience of business failure. We utilize rich longitudinal data tracking the careers and well-being of individuals over time. Specifically, we study the life and health satisfaction associated with business exits. We not only explore involuntary selfemployment exits (i.e., transitions from selfemployment to unemployment) but also consider how psychological well-being and health satisfaction change after voluntarily transitioning to salaried employment following a business exit. Finally, we compare the subjective well-being consequences of exiting selfemployment to those associated with similar transitions from salaried employment. Such insights are equally important when assessing the potential returns from starting a new business. They can be particularly relevant for public policy, especially that small business activity is highly valued and supported by governments around the world.

Our findings suggest that the life and health satisfaction of the self-employed decrease drastically if the business exit is followed by an unemployment spell. Compared with previous studies documenting mental and sometimes physical health gains of switching to self-employment (Nikolova 2019), our results indicate that the potential well-being costs of business failure can be much larger than the benefits from starting a new business venture. For many people, fear of failure is a significant obstacle to starting a business (Cacciotti et al. 2016). This fear of failure may, in part, be informed by the high rates of business exits and the negative emotions they trigger. This can explain why even though many people prefer working for themselves, only a small fraction of people take a leap in starting new ventures, especially in the developed world where salaried employment presents a viable alternative (Parker 2019).

Our results also suggest that the psychological costs of business failure significantly exceed the costs of involuntary loss of a salaried job, implying that the unemployment experience is particularly psychologically damaging for those losing self-employment. Even more importantly, the well-being costs of business failure can be long-lasting and scarring. Specifically, we find that life satisfaction does not recover even 2 or more years after a business exit that leads to unemployment. Meanwhile, transitioning to private sector employment brings mild improvements in psychological well-being and health satisfaction, both for those who leave selfemployment and for those who switch from one private sector job to another. This implies that finding 
alternative salaried employment can cushion the psychological costs of business failure. In this respect, public programs directed at helping failed entrepreneurs integrate quickly into the labor market can lead to significant welfare gains.

Acknowledgments The authors would like to thank the Managing Editor, Adam Lederer, and an anonymous referee for thorough and thoughtful feedback. In addition, we are grateful to Antje Schmitt, Nils Rietveld, Anne-Kathrin Kleine, and participants in the Research Meeting: Psychological Perspectives on Entrepreneurship in Groningen for helpful comments and suggestions. All errors are our own.

Funding information Popova acknowledges the support from Russian Science Foundation grant no. 19-18-00262.

Open Access This article is licensed under a Creative Commons Attribution 4.0 International License, which permits use, sharing, adaptation, distribution and reproduction in any medium or format, as long as you give appropriate credit to the original author(s) and the source, provide a link to the Creative Commons licence, and indicate if changes were made. The images or other third party material in this article are included in the article's Creative Commons licence, unless indicated otherwise in a credit line to the material. If material is not included in the article's Creative Commons licence and your intended use is not permitted by statutory regulation or exceeds the permitted use, you will need to obtain permission directly from the copyright holder. To view a copy of this licence, visit http://creativecommons.org/licenses/by/4.0/.

\section{References}

Armour, J., \& Cumming, D. (2008). Bankruptcy law and entrepreneurship. American Law and Economics Review, 10(2), 303-350 Available at: https://www.jstor. org/stable/42705535.

Bartrum, D., \& Creed, P. A. (2006). Explanations for deteriorating wellbeing in unemployed people: Specific unemployment theories and beyond. In T. Kieselbach, A. H. Winefield, C. Boyd, \& S. Anderson (Eds.), Unemployment and health: International and interdisciplinary perspectives (pp. 1-20). Brisbane: Australian Academic Press ISBN: 9781875378616.

Bates, T. (2005). Analysis of young, small firms that have closed: delineating successful from unsuccessful closures. Journal of Business Venturing, 20(3), 343-358. https://doi.org/10.1016 /j.jbusvent.2004.01.003.

Benz, M., \& Frey, B. S. (2008a). Being independent is a great thing: Subjective evaluations of self-employment and hierarchy. Economica, 75(298), 362-383. https://doi.org/10.1111 j.1468-0335.2007.00594.x.

Benz, M., \& Frey, B. S. (2008b). The value of doing what you like: Evidence from the self-employed in 23 countries. Journal of Economic Behavior \& Organization, 68(3/4), 445-455. https://doi.org/10.1016/j.jebo.2006.10.014.
Binder, M., \& Coad, A. (2013). Life satisfaction and self-employment: A matching approach. Small Business Economics, 40(4), 1009-1033. https://doi.org/10.1007/s11187-0119413-9.

Boswell, W. R., Boudreau, J. W., \& Tichy, J. (2005). The relationship between employee job change and job satisfaction: The honeymoon-hangover effect. Journal of Applied Psychology, 90(5), 882. https://doi.org/10.1037/00219010.90.5.882.

Bubonya, M., Cobb-Clark, D. A., \& Wooden, M. (2017). Job loss and the mental health of spouses and adolescent children. IZA Journal of Labor Economics, 6(1), 6. https://doi.org/10.1186 /s40172-017-0056-1.

Byrne, O., \& Shepherd, D. A. (2015). Different strokes for different folks: Entrepreneurial narratives of emotion, cognition, and making sense of business failure. Entrepreneurship Theory and Practice, 39(2), 375-405. https://doi. org/10.1111/etap.12046.

Cacciotti, G., Hayton, J. C., Mitchell, J. R., \& Giazitzoglu, A. (2016). A reconceptualization of fear of failure in entrepreneurship. Journal of Business Venturing, 31(3), 302-325. https://doi.org/10.1016/j.jbusvent.2016.02.002.

Cardon, M. S., \& Patel, P. C. (2015). Is stress worth it? Stressrelated health and wealth trade-offs for entrepreneurs. Applied Psychology, 64(2), 379-420. https://doi. org/10.1111/apps.12021.

Cardon, M. S., Foo, M. D., Shepherd, D., \& Wiklund, J. (2012). Exploring the heart: Entrepreneurial emotion is a hot topic. Entrepreneurship Theory and Practice, 36(1), 1-10. https://doi.org/10.1111/j.1540-6520.2011.00501.x.

Chadi, A., \& Hetschko, C. (2018). The magic of the new: How job changes affect job satisfaction. Journal of Economics \& Management Strategy, 27(1), 23-39. https://doi. org/10.1111/jems.12217.

Clark, A. E. (2016). Adaptation and the Easterlin Paradox. In T. Tachibanaki (Ed.), Advances in Happiness Research (pp. 75-94). Springer ISBN: 9784431557524.

Clark, A. E., \& Georgellis, Y. (2013). Back to baseline in Britain: Adaptation in the British household panel survey. Economica, 80(319), 496-512. https://doi.org/10.1111 /ecca.12007.

Clark, A. E., Georgellis, Y., \& Sanfey, P. (2001). Scarring: The psychological impact of past unemployment. Economica, 68(270), 221-241. https://doi.org/10.1111/14680335.00243 .

Clark, A. E., D'Ambrosio, C., \& Ghislandi, S. (2016). Adaptation to poverty in long-run panel data. Review of Economics and Statistics, 98(3), 591-600. https://doi.org/10.1162/REST_ a_00544.

Coad, A. (2014). Death is not a success: Reflections on business exit. International Small Business Journal, 32(7), 721-732. https://doi.org/10.1177/0266242612475104.

Cohen, J. (1992). A power primer. Psychological Bulletin, 112(1), 155-159. https://doi.org/10.1037/0033-2909.112.1.155.

de Bruin, S. R., Heijink, R., Lemmens, L. C., Struijs, J. N., \& Baan, C. A. (2011). Impact of disease management programs on healthcare expenditures for patients with diabetes, depression, heart failure or chronic obstructive pulmonary disease: A systematic review of the literature. Health Policy, 101(2), 105-121. https://doi.org/10.1016/j.healthpol.2011.03.006. 
Deb, P., Gallo, W. T., Ayyagari, P., Fletcher, J. M., \& Sindelar, J. L. (2011). The effect of job loss on overweight and drinking. Journal of Health Economics, 30(2), 317-327. https://doi. org/10.1016/j.jhealeco.2010.12.009.

Fairlie, R. W., \& Fossen, F. M. (2018). Opportunity versus necessity entrepreneurship: Two components of business creation. IZA Discussion Paper 11258. Available online: http://ftp.iza. org/dp11258.pdf

Faragher, E. B., Cass, M., \& Cooper, C. L. (2005). The relationship between job satisfaction and health: A meta-analysis. Occupational and Environmental Medicine, 62(2), 105-112. https://doi.org/10.1136/oem.2002.006734.

Georgellis, Y., \& Yusuf, A. (2016). Is becoming self-employed a panacea for job satisfaction? Longitudinal evidence from work to self-employment transitions. Journal of Small Business Management, 54, 53-76. https://doi.org/10.1111 /jsbm.12292.

Gielen, A. C., \& van Ours, J. C. (2014). Unhappiness and job finding. Economica, 81(323), 544-565. https://doi. org/10.1111/ecca.12089.

Goebel, J., Grabka, M., Liebig, S., Kroh, M., Richter, D., Schröder, C., \& Schupp, J. (2019). The German SocioEconomic Panel (SOEP). Jahrbücher für Nationalökonomie und Statistik, 239(2), 345-360. https://doi.org/10.1515/jbnst2018-0022.

Graham, C. (2011). Adaptation amidst prosperity and adversity: Insights from happiness studies from around the world. The World Bank Research Observer, 26(1), 105-137. https://doi. org/10.1093/wbro/lkq004.

Grilli, L. (2011). When the going gets tough, do the tough get going? The pre-entry work experience of founders and hightech start-up survival during an industry crisis. International Small Business Journal, 29(6), 626-647. https://doi. org/10.1177/0266242610372845.

Hainmueller, J. (2012). Entropy balancing for causal effects: A multivariate reweighting method to produce balanced samples in observational studies. Political Analysis, 20(1), 2546. https://doi.org/10.1093/pan/mpr025.

Hainmueller, J., \& Xu, Y. (2013). ebalance: A Stata package for entropy balancing. Journal of Statistical Software, 54(7), 118. https://doi.org/10.18637/jss.v054.i07.

Hanglberger, D., \& Merz, J. (2015). Does self-employment really raise job satisfaction? Adaptation and anticipation effects on self-employment and general job changes. Journal for Labour Market Research, 48(4), 287-303. https://doi. org/10.1007/s12651-015-0175-8.

Hessels, J., Rietveld, C. A., \& van der Zwan, P. (2017). Selfemployment and work-related stress: The mediating role of job control and job demand. Journal of Business Venturing, 32(2), 178-196. https://doi.org/10.1016/j. jbusvent.2016.10.007.

Hessels, J., Arampatzi, E., van der Zwan, P., \& Burger, M. (2018). Life satisfaction and self-employment in different types of occupations. Applied Economics Letters, 25(11), 734-740. https://doi.org/10.1080/13504851.2017.1361003.

Hetschko, C., Knabe, A., \& Schöb, R. (2014). Changing identity: retiring from unemployment. The Economic Journal, 124(575), 149-166. https://doi.org/10.1111/ecoj.12046.

Hetschko, C. (2016). On the misery of losing self-employment. Small Business Economics, 47(2), 461-478. https://doi. org/10.1007/s11187-016-9730-0.
Hundley, G. (2001). Why and when are the self-employed more satisfied with their work? Industrial Relations: A Journal of Economy and Society, 40(2), 293-316. https://doi. org/10.1111/0019-8676.00209.

Jahoda, M. (1982). Employment and unemployment: A socialpsychological analysis. London: Cambridge University Press ISBN: 9780521285865.

Jahoda, M. (1987). Unemployed men at work. In D. Fryer \& P. Ullah (Eds.), Unemployed people: Social and psychological perspectives (pp. 1-73). Milton Keynes: Open University Press ISBN: 9780335155064.

Janicki-Deverts, D., Cohen, S., Matthews, K. A., \& Cullen, M. R. (2008). History of unemployment predicts future elevations in C-reactive protein among male participants in the coronary artery risk development in young adults (CARDIA) study. Annals of Behavioral Medicine, 36(2), 176-185. https://doi. org/10.1007/s12160-008-9056-5.

Jenkins, A. S., \& McKelvie, A. (2017). Is this the end? Investigating firm and individual level outcomes post-failure. Journal of Business Venturing Insights, 8, 138-143. https://doi.org/10.1016/j.jbvi.2017.10.002.

Jenkins, A. S., Wiklund, J., \& Brundin, E. (2014). Individual responses to firm failure: Appraisals, grief, and the influence of prior failure experience. Journal of Business Venturing, 29(1), 17-33. https://doi.org/10.1016/j. jbusvent.2012.10.006.

Judge, T. A., \& Watanabe, S. (1993). Another look at the job satisfaction-life satisfaction relationship. Journal of Applied Psychology, 78(6), 939-948. https://doi.org/10.1037/00219010.78.6.939.

Judge, T. A., Locke, E. A., Durham, C. C., \& Kluger, A. N. (1998). Dispositional effects on job and life satisfaction: The role of core evaluations. Journal of Applied Psychology, 83(1), 17-34. https://doi.org/10.1037/00219010.83.1.17.

Kassenboehmer, S. C., \& Haisken-DeNew, J. P. (2009). You're fired! The causal negative effect of entry unemployment on life satisfaction. The Economic Journal, 119(536), 448-462. https://doi.org/10.1111/j.1468-0297.2008.02246.x.

Katz, J., \& Gartner, W. B. (1988). Properties of emerging organizations. Academy of Management Review, 13(3), 429-441 Available at https://www.jstor.org/stable/258090.

King, G., \& Nielsen, R. (2019). Why propensity scores should not be used for matching. Political Analysis, 27(4), 435-454. https://doi.org/10.1017/pan.2019.11.

Korpi, T. (2001). Accumulating disadvantage. Longitudinal analyses of unemployment and physical health in representative samples of the Swedish population. European Sociological Review, 17(3), 255-273. https://doi.org/10.1093 /esr/17.3.255.

Kunze, L., \& Suppa, N. (2020). The effect of unemployment on social participation of spouses: Evidence from plant closures in Germany. Empirical Economics, 58, 815-833. https://doi. org/10.1007/s00181-018-1542-4.

Maier, R., Egger, A., Barth, A., Winker, R., Osterode, W., Kundi, M., Wolf, C., \& Ruediger, H. (2006). Effects of short-and long-term unemployment on physical work capacity and on serum cortisol. International Archives of Occupational and Environmental Health, 79(3), 193-198. https://doi. org/10.1007/s00420-005-0052-9. 
Marcus, J. (2013). The effect of unemployment on the mental health of spouses - Evidence from plant closures in Germany. Journal of Health Economics, 32(3), 546-558. https://doi.org/10.1016/j.jhealeco.2013.02.004.

Marcus, J. (2014). Does job loss make you smoke and gain weight? Economica, 81(324), 626-648. https://doi. org/10.1111/ecca.12095.

McKee-Ryan, F., Song, Z., Wanberg, C. R., \& Kinicki, A. J. (2005). Psychological and physical well-being during unemployment: A meta-analytic study. Journal of Applied Psychology, 90(1), 53-76. https://doi.org/10.1037/00219010.90.1.53.

Nikolaev, B., Boudreaux, C. J., \& Wood, M. (2020). Entrepreneurship and subjective well-being: The mediating role of psychological functioning. Entrepreneurship Theory and Practice, 44(3), 557-586. https://doi.org/10.1177 $/ 1042258719830314$.

Nikolova, M. (2019). Switching to self-employment can be good for your health. Journal of Business Venturing, 34(4), 664691. https://doi.org/10.1016/j.jbusvent.2018.09.001.

Nikolova, M., \& Ayhan, S. H. (2019). Your spouse is fired! How much do you care? Journal of Population Economics, 32(3), 799-844. https://doi.org/10.1007/s00148-018-0693-0.

O’Neill, S., Kreif, N., Grieve, R., Sutton, M., \& Sekhon, J. S. (2016). Estimating causal effects: Considering three alternatives to difference-in-differences estimation. Health Services and Outcomes Research Methodology, 16(1-2), 1-21. https://doi.org/10.1007/s10742-016-0146-8.

Parker, S. C. (2019). The economics of self-employment and entrepreneurship. Cambridge: Cambridge University Press. ISBN: 9780511493430. https://doi.org/10.1017 /CBO9780511493430.

Paternoster, R., Brame, R., Mazerolle, P., \& Piquero, A. (1998). Using the correct statistical test for the equality of regression coefficients. Criminology, 36(4), 859-866. https://doi. org/10.1111/j.1745-9125.1998.tb01268.x.

Patzelt, H., \& Shepherd, D. A. (2011). Negative emotions of an entrepreneurial career: Self-employment and regulatory coping behaviors. Journal of Business Venturing, 26(2), 226238. https://doi.org/10.1016/j.jbusvent.2009.08.002.

Paul, K. I., \& Moser, K. (2009). Unemployment impairs mental health: Meta-analyses. Journal of Vocational Behavior, 74(3), 264-282. https://doi.org/10.1016/j.jvb.2009.01.001.

Platt, S., \& Hawton, K. (2000). Suicidal behaviour and the labor market. In K. Hawton \& K. van Heeringen (Eds.), The international handbook of suicide and attempted suicide (pp. 309-384). West Sussex: Wiley ISBN: 9780471983675.

Price, R. H., Choi, J. N., \& Vinokur, A. D. (2002). Links in the chain of adversity following job loss: How financial strain and loss of personal control lead to depression, impaired functioning, and poor health. Journal of Occupational Health Psychology, 7(4), 302-312. https://doi.org/10.1037 /1076-8998.7.4.302.

Qari, S. (2014). Marriage, adaptation and happiness: Are there long-lasting gains to marriage? Journal of Behavioral and Experimental Economics, 50, 29-39. https://doi.org/10.1016 /j.socec.2014.01.003.

Reynolds, P. D., Carter, N. M., Gartner, W. B., \& Greene, P. G. (2004). The prevalence of nascent entrepreneurs in the United States: Evidence from the panel study of entrepreneurial dynamics. Small Business Economics, 23(4), 263-284. https://doi.org/10.1023 /B:SBEJ.0000032046.59790.45.

Rietveld, C. A., van Kippersluis, H., \& Thurik, A. R. (2015). Selfemployment and health: Barriers or benefits? Health Economics, 24(10), 1302-1313. https://doi.org/10.1002 /hec.3087.

Ronstadt, R. (1986). Exit, stage left why entrepreneurs end their entrepreneurial careers before retirement. Journal of Business Venturing, 1(3), 323-338. https://doi.org/10.1016/08839026(86)90008-X.

Rouse, E. D. (2016). Beginning's end: How founders psychologically disengage from their organizations. Academy of Management Journal, 59(5), 1605-1629. https://doi. org/10.5465/amj.2013.1219.

Ryan, A. M., Kontopantelis, E., Linden, A., \& Burgess, J. F. (2019). Now trending: Coping with non-parallel trends in difference-in-differences analysis. Statistical Methods in Medical Research, 28(12), 3697-3711. https://doi. org/10.1177/0962280218814570.

Schmitz, H. (2011). Why are the unemployed in worse health? The causal effect of unemployment on health. Labour Economics, 18(1), 71-78. https://doi.org/10.1016/j.labeco.2010.08.005.

Shane, S. A. (2008). The illusions of entrepreneurship: The costly myths that entrepreneurs, investors, and policy makers live by. New Haven: Yale University Press ISBN: 9780300113310.

Shepherd, D. A. (2003). Learning from business failure: Propositions of grief recovery for the self-employed. Academy of Management Review, 28(2), 318-328. https://doi.org/10.5465/amr.2003.9416377.

Shepherd, D. A., Covin, J. G., \& Kuratko, D. F. (2009a). Project failure from corporate entrepreneurship: Managing the grief process. Journal of Business Venturing, 24(6), 588-600. https://doi.org/10.1016/j.jbusvent.2008.01.009.

Shepherd, D. A., Wiklund, J., \& Haynie, J. M. (2009b). Moving forward: Balancing the financial and emotional costs of business failure. Journal of Business Venturing, 24(2), 134 148. https://doi.org/10.1016/j.jbusvent.2007.10.002.

Shir, N., Nikolaev, B. N., \& Wincent, J. (2019). Entrepreneurship and well-being: The role of psychological autonomy, competence, and relatedness. Journal of Business Venturing, 34(5), 105875 . https://doi.org/10.1016/j. jbusvent.2018.05.002.

Simmons, S. A., Wiklund, J., \& Levie, J. (2014). Stigma and business failure: Implications for entrepreneurs' career choices. Small Business Economics, 42(3), 485-505. https://doi.org/10.1007/s11187-013-9519-3.

Stephan, U. (2018). Entrepreneurs' mental health and well-being: A review and research agenda. Academy of Management Perspectives, 32(3), 290-322. https://doi.org/10.5465 /amp.2017.0001.

Stephan, U., \& Roesler, U. (2010). Health of entrepreneurs versus employees in a national representative sample. Journal of Occupational and Organizational Psychology, 83(3), 717738. https://doi.org/10.1348/096317909X472067.

Stephan, U., Li, J., \& Qu, J. (2020). A fresh look at self-employment, stress and health: Accounting for self-selection, time and gender. International Journal of Entrepreneurial Behavior \& Research https://www.emerald. com/insight/1355-2554.htm. 
Strully, K. W. (2009). Job loss and health in the US labor market. Demography, 46(2), 221-246. https://doi.org/10.1353 /dem.0.0050.

Ucbasaran, D., Shepherd, D. A., Lockett, A., \& Lyon, S. J. (2013). Life after business failure: The process and consequences of business failure for entrepreneurs. Journal of Management, 39(1), 163-202. https://doi.org/10.1177 /0149206312457823.

Uy, M. A., Foo, M.-D., \& Song, Z. (2013). Joint effects of prior start-up experience and coping strategies on entrepreneurs' psychological well-being. Journal of Business Venturing, 28(5), 583-597. https://doi.org/10.1016/j. jbusvent.2012.04.003.

Wagner, G., Frick, J. R., \& Schupp, J. (2007). The German SocioEconomic Panel study (SOEP)-scope, evolution and enhancements. Schmollers Jahrbuch: Journal of Applied Social Science Studies, 127(1), 139-169.

Wanberg, C. R. (2012). The individual experience of unemployment. Annual Review of Psychology, 63, 369-396. https://doi.org/10.1146/annurev-psych-120710-100500.

Wasserman, N. (2008). The founder's dilemma. Harvard Business Review, 86(2), 102-109 Available at: https://hbr.org/2008/02 the-founders-dilemma.

Waters, L. E. (2000). Coping with unemployment: A literature review and presentation of a new model. International
Journal of Management Reviews, 2(2), 169-182. https://doi.org/10.1111/1468-2370.00036.

Wiklund, J., Nikolaev, B., Shir, N., Foo, M.-D., \& Bradley, S. (2019). Entrepreneurship and well-being: Past, present, and future. Journal of Business Venturing, 34(4), 579-588. https://doi.org/10.1016/j.jbusvent.2019.01.002.

Wincent, J., \& Örtqvist, D. (2011). Examining positive performance implications of role stressors by the indirect influence of positive affect: A study of new business managers. Journal of Applied Social Psychology, 41(3), 699-727. https://doi. org/10.1111/j.1559-1816.2011.00733.x.

Wolfe, M. T., \& Patel, P. C. (2019). Exploring the differences in perceptions of work importance and job usefulness to society between self-employed and employed individuals. Journal of Business Venturing Insights, 12, e00146. https://doi. org/10.1016/j.jbvi.2019.e00146.

Zimmermann, A. C., \& Easterlin, R. A. (2006). Happily ever after? Cohabitation, marriage, divorce, and happiness in Germany. Population and Development Review, 32(3), 511-528. https://doi.org/10.1111/j.1728-4457.2006.00135. $\mathrm{x}$.

Publisher's note Springer Nature remains neutral with regard to jurisdictional claims in published maps and institutional affiliations. 